\title{
UNIVERSITYOF BIRMINGHAM

Platelet Activation by Vaccine-Induced Immune Thrombotic Thrombocytopenia (VITT) Patient Serum is Blocked by COX, P2Y12 and Kinase Inhibitors

Smith, Christopher; Kardeby, Caroline; Di, Ying; Lowe, Gillian; Lester, William; Watson, Steve; Nicolson, Phillip

DOI:

10.1101/2021.04.24.21255655

License:

None: All rights reserved

Document Version

Early version, also known as pre-print

Citation for published version (Harvard):

Smith, C, Kardeby, C, Di, Y, Lowe, G, Lester, W, Watson, S \& Nicolson, P 2021, 'Platelet Activation by VaccineInduced Immune Thrombotic Thrombocytopenia (VITT) Patient Serum is Blocked by COX, P2Y12 and Kinase Inhibitors', medRxiv, vol. 2021, pp. 1-23. https://doi.org/10.1101/2021.04.24.21255655

Link to publication on Research at Birmingham portal

\section{General rights}

Unless a licence is specified above, all rights (including copyright and moral rights) in this document are retained by the authors and/or the copyright holders. The express permission of the copyright holder must be obtained for any use of this material other than for purposes permitted by law.

-Users may freely distribute the URL that is used to identify this publication.

- Users may download and/or print one copy of the publication from the University of Birmingham research portal for the purpose of private study or non-commercial research.

- User may use extracts from the document in line with the concept of 'fair dealing' under the Copyright, Designs and Patents Act 1988 (?)

- Users may not further distribute the material nor use it for the purposes of commercial gain.

Where a licence is displayed above, please note the terms and conditions of the licence govern your use of this document.

When citing, please reference the published version.

Take down policy

While the University of Birmingham exercises care and attention in making items available there are rare occasions when an item has been uploaded in error or has been deemed to be commercially or otherwise sensitive.

If you believe that this is the case for this document, please contact UBIRA@lists.bham.ac.uk providing details and we will remove access to the work immediately and investigate. 


\section{Platelet Activation by Vaccine-Induced Immune Thrombotic Thrombocytopenia (VITT) Patient Serum is Blocked by COX, $\mathrm{P}^{2} \mathrm{Y}_{12}$ and Kinase Inhibitors}

Christopher W. Smith, PhD ${ }^{1}$; Caroline Kardeby, $\mathrm{PhD}{ }^{1}$; Ying Di, MRes ${ }^{1}$; Gillian C. Lowe, MD, PhD ${ }^{2}$; William A. Lester, MD, PhD ${ }^{2}$; Steve P. Watson, PhD ${ }^{1}$; Phillip L.R. Nicolson, $\mathrm{MD}, \mathrm{PhD}{ }^{1,2}$

${ }^{1}$ Institute of Cardiovascular Sciences, College of Medical and Dental Sciences, University of Birmingham, Birmingham, B15 2TT, UK

${ }^{2}$ Comprehensive Care Haemophilia Centre, University Hospitals Birmingham NHS Foundation Trust, Birmingham, B15 2TH, UK

Corresponding author: Phillip L.R. Nicolson, email: p.nicolson@bham.ac.uk 
medRxiv preprint doi: https://doi.org/10.1101/2021.04.24.21255655; this version posted April 27, 2021. The copyright holder for this preprint (which was not certified by peer review) is the author/funder, who has granted medRxiv a license to display the preprint in perpetuity. All rights reserved. No reuse allowed without permission.

\section{Key points}

1. Serum from patients with VITT activates platelets via the FcyRIIA.

2. Platelet activation by serum from patients with VITT can be blocked by COX, P2Y $\mathrm{Y}_{12}$, Src, Syk and Btk inhibition.

Key words: VITT, VIPIT, FcYRIIA, AZD1222, COVID vaccination

Abstract word count: 267

Manuscript word count: 2440

Number of figures: 2

Number of tables: 1 


\section{Abstract}

\section{Background}

The novel coronavirus SARS-CoV-2 has caused a global pandemic. Vaccines are an important part of the response. Although rare, unusual thrombotic events and thrombocytopenia in recipients 4-16 days after vaccination with the AstraZeneca AZD1222 have been reported. This syndrome of vaccine-induced immune thrombotic thrombocytopenia (VITT) clinically resembles heparin induced thrombocytopenia (HIT), which is caused by platelet activating antibodies against platelet factor 4 (PF4). Here, we investigate the effect of serum from patients with VITT on platelet activation, and assess the ability of clinically available therapeutics to prevent platelet activation.

\section{Methods}

Aggregation responses of healthy donor washed platelets were assessed in response to serum from patients with VITT pre- and post-intravenous immunoglobulin (IVIg) treatment and in the presence of anti-FcyRIIA blocking IV.3 F(ab), anti-platelet drugs and kinase inhibitors.

\section{Findings}

Four patients (21 - 48 years old) presented with thrombosis (three patients: cerebral venous sinus thrombosis, one patient: ischemic stroke) and thrombocytopenia 10-14 days after AZD1222 vaccination. All patients tested positive for anti-PF4 antibody despite no prior heparin exposure. Serum from patients with VITT, but not healthy donor controls, induced platelet aggregation, which was abrogated following IVIg treatment. Aggregation to patient sera was blocked by IV.3 F(ab) which targets FcyRIIA, and inhibitors of Src, Syk and Btk kinases downstream of the receptor. Anti-platelet therapies indomethacin and ticagrelor also blocked aggregation. 
medRxiv preprint doi: https://doi.org/10.1101/2021.04.24.21255655; this version posted April 27, 2021. The copyright holder for this preprint (which was not certified by peer review) is the author/funder, who has granted medRxiv a license to display the preprint in perpetuity. All rights reserved. No reuse allowed without permission.

\section{Interpretation}

In conclusion, serum from patients with VITT activates platelets via the FcyRIIA, which can be blocked in vitro by anti-platelet therapies suggesting possible new therapeutic interventions for this rare syndrome.

\section{Funding}

This work was supported by an Accelerator Grant (AA/18/2/34218) from the British Heart Foundation (BHF). 
medRxiv preprint doi: https://doi.org/10.1101/2021.04.24.21255655; this version posted April 27, 2021. The copyright holder for this preprint (which was not certified by peer review) is the author/funder, who has granted medRxiv a license to display the preprint in perpetuity.

\section{Introduction}

The respiratory disease COVID-19, caused by the novel coronavirus, severe acute respiratory syndrome coronavirus 2 (SARS-CoV-2), has caused a global pandemic and millions of deaths. To combat this, several vaccines have been developed. ${ }^{1-3}$ The OxfordAstraZeneca chimpanzee adenovirus vectored ChAdOx1 nCoV-19 (AZD1222) vaccine has been used in an aggressive vaccination program in the UK and across the European Economic Area due to its low cost and ease of storage ( 20 million people vaccinated as of $08 / 04 / 2021){ }^{4}$

However, since late February 2021 there have been a growing number reports of unusual thrombotic events with accompanying thrombocytopenia, disseminated intravascular coagulation (DIC) and bleeding with high mortality 4-16 days post vaccination with AZD1222 in young and healthy individuals leading to concerns this is a vaccine-induced condition. 5,6 This has been termed vaccine-induced immune thrombotic thrombocytopenia (VITT) and has an approximate incidence of 1 in $250,000 .^{5,7}$

VITT has a clinical resemblance to autoimmune heparin induced thrombocytopenia (HIT), with several patients testing positive for anti-platelet factor 4 (PF4) antibodies. ${ }^{5,8}$ In HIT, IgG-containing immune complexes bind and cross-link the platelet surface receptor FcyRIIA (CD32a), a low affinity Fc receptor (FcR) that binds immune complexes with high avidity, and initiate platelet activation. ${ }^{8}$ Autoimmune HIT, despite the name, can rarely occur independently of heparin and result in persistent severe thrombocytopenia together with DIC and microvascular thrombosis. ${ }^{8}$

In this study, we investigated the effect of serum from patients with VITT on platelet aggregation. Serum from patients with VITT induced aggregation of healthy donor platelets in vitro. This was abolished following treatment of patients with intravenous immunoglobulin 
medRxiv preprint doi: https://doi.org/10.1101/2021.04.24.21255655; this version posted April 27, 2021. The copyright holder for this preprint

(which was not certified by peer review) is the author/funder, who has granted medRxiv a license to display the preprint in perpetuity.

All rights reserved. No reuse allowed without permission.

(IVIg) or, in vitro, following heat inactivation of patient serum, in the presence of an anti-

FcyRIIA monoclonal antibody blocking $F(a b)$, or inhibitors of FcyRIIA downstream signalling kinases and platelet feedback agonists.

\section{Methods}

\section{Patients and Ethical approval}

Patients presenting with thrombosis and thrombocytopenia, occurring after AZD1222 vaccination were recruited. Collection of blood from these patients (including those lacking capacity) was approved under research ethics granted to the University of Birmingham Human Biomaterial Resource Centre (North West - Haydock Research Ethics Committee, reference: 15/NW/0079, amendment 3, 19/11/2018). Ethical approval for collecting blood from healthy volunteers was granted by Birmingham University Internal Ethical Review Committee (reference: ERN_11-0175, assessed 22/3/2021).

\section{Antibodies and reagents}

Mouse monoclonal IgG2b antibody against human CD32 (IV.3) was purified from hybridoma cells supernatant, and IV.3 F(ab) fragment made using Pierce Fab Preparation kit (Thermo Fisher Scientific). Eptifibatide was from GSK. Ibrutinib (PCl-32765), R406 (free base), entospletinib (GS-9973) were from Selleckchem. Rilzabrutinib was provided by Principia BioPharma. All other reagents were purchased from Sigma-Aldrich. 
medRxiv preprint doi: https://doi.org/10.1101/2021.04.24.21255655; this version posted April 27, 2021. The copyright holder for this preprint (which was not certified by peer review) is the author/funder, who has granted medRxiv a license to display the preprint in perpetuity.

\section{Serum preparation}

Patient and healthy donor serum was collected following centrifugation $(2000 \times \mathrm{g}, 10$ minutes, room temperature $[\mathrm{RT}])$ of clotted whole blood. Patient sera was collected before and after treatment with dexamethasone and IVIg (see Table 1).

\section{Human platelet preparation}

Preparation of washed platelets from citrated whole blood has already been described. ${ }^{9}$ Briefly; citrated blood was taken from healthy, drug-free volunteers and mixed $(1: 10, v / v)$ with acid citrate dextrose and centrifuged (200 $\times \mathrm{g}, 20$ minutes, RT) to produce platelet rich plasma. Platelet rich plasma was then centrifuged $(1000 \times \mathrm{g}, 10$ minutes, RT) in the presence of $0.2 \mu \mathrm{g} / \mathrm{ml}$ prostacyclin. The platelet pellet was resuspended in modifiedTyrode's-HEPES buffer, acid citrate dextrose and $0.2 \mu \mathrm{g} / \mathrm{ml}$ prostacyclin and centrifuged $(1000 \times \mathrm{g}, 10$ minutes, RT). Platelet pellet was resuspended in modified-Tyrode's-HEPES buffer to a concentration of $2 \times 10^{8} / \mathrm{ml}$ and allowed to rest for 30 minutes prior to use.

\section{Light transmission aggregometry (LTA)}

Aggregation was measured in washed platelets $\left(2 \times 10^{8} / \mathrm{ml}\right)$ under stirring conditions (1200 rpm) at $37^{\circ} \mathrm{C}$ using a light transmission aggregometer (Model 700, ChronoLog) for 20 minutes following stimulation with serum $(1: 15, \mathrm{v} / \mathrm{v})$. Washed platelets were pre-incubated with IV.3 $\mathrm{F}(\mathrm{ab})$ for 5 minutes or with inhibitors for 10 minutes prior to stimulation with serum. Tyrode's or dimethyl sulfoxide (DMSO) was used as vehicle.

\section{Statistical analysis}

All data are presented as mean \pm standard error of the mean (SEM), $p<0.05$ was considered statistically significant. Statistical analysis was performed in GraphPad Prism 9 (GraphPad Software Inc.) using one or two-way ANOVA with Dunnett corrections for multiple comparisons. 
medRxiv preprint doi: https://doi.org/10.1101/2021.04.24.21255655; this version posted April 27, 2021. The copyright holder for this preprint (which was not certified by peer review) is the author/funder, who has granted medRxiv a license to display the preprint in perpetuity.

\section{Role of the funding source}

Funding sources were not involved in study design; collection, analysis, or interpretation of data; writing of the report; or in the decision to submit the paper for publication. All authors had full access to study data and accept responsibility to submit for publication.

\section{Results}

\section{Patients with VITT demonstrate thrombosis, thrombocytopenia, elevated D-dimer levels and anti-PF4 antibodies on ELISA testing}

The presentation, investigation results, treatment and outcomes of four patients with VITT are summarized in Table 1. All patients were Caucasian and under the age of 50 , and had not previously had symptomatic COVID-19. All patients presented with headaches, and one also had expressive dysphasia, 10-14 days following dosing with AZD1222. At presentation clinical investigation revealed that all patients were thrombocytopenic (range: $7-113 \times 10^{9}$ platelets/L), with massively elevated D-dimer and low fibrinogen levels. Despite no prior exposure to heparin, HIT screening with the anti-PF4 IgG Immucor assay showed strong reactivity in all patients, with Heparin Induced Platelet Activation (HIPA) assays in the three patients tested showing platelet activation to patient serum that was reduced by low and blocked by high concentrations of heparin. These results are similar to reports of other patients with VITT. ${ }^{5,6}$ Cross-sectional brain imaging verified the presence of cerebral venous sinus thrombosis (CVST) and intracerebral haemorrhage in three patients, and ischemic stroke caused by internal carotid artery thrombus in one patient.

All patients received intravenous immunoglobulin (IVIg) and the steroid dexamethasone, which is recommended by the British Society of Haematology guidelines for $\mathrm{VITT}^{10}$, and all had rapid improvements in their platelet counts over 1-3 days. Of note, IVIg has also been 
medRxiv preprint doi: https://doi.org/10.1101/2021.04.24.21255655; this version posted April 27, 2021. The copyright holder for this preprint (which was not certified by peer review) is the author/funder, who has granted medRxiv a license to display the preprint in perpetuity.

shown to rapidly inhibit HIT antibody induced platelet activation. ${ }^{11}$ Patients also received non-heparin anticoagulation, and two patients required intensive care unit support. At the time of writing, three patients had recovered and been discharged from hospital and one patient died in the intensive care unit.

\section{Serum from patients with VITT induces platelet aggregation}

Serum was collected from healthy donors and patients with VITT. Patient 1 had serum collected after IVIg had been administered. Patients 2, 3 and 4 had serum collected both before and after IVIg administration. Patient 2 had received dexamethasone prior to their first serum collection. To investigate the effect on platelet activation, these sera were added to washed platelets and aggregation measured (Figure 1A). Serum from patients with VITT triggered platelet aggregation to variable degrees depending on the platelet donor, which was abolished in post-IVIg treatment sera. Sera from four healthy donor controls did not cause platelet aggregation. Three repeats were performed for each serum sample on platelets from healthy donors known to respond.

Addition of the integrin allbß3 inhibitor eptifibatide $(9 \mu \mathrm{M})$ inhibited the response to patient sera, confirming that this was aggregation rather than agglutination (data not shown).

\section{Platelet aggregation to serum from patients with VITT is abolished by FcyRIIA blockade and heat inactivation}

Platelet activation in HIT is caused by antibody mediated clustering of FcyRIIA. ${ }^{8}$ To determine if a similar mechanism was involved in VITT we used an anti-FcyRIIA blocking IV.3 $F(a b)$. Platelet activation by patient sera was abolished in the presence of IV.3 F(ab) demonstrating platelet activation in VITT is mediated via FcyRIIA. 
The involvement of PF4 and heparin in HIT led us to evaluate their effects in conjunction with patient sera. Both PF4 and low concentrations of heparin have been shown to enhance platelet responses in HIT assays, whereas heparin at high concentrations inhibits any response. $^{12-14}$ No enhancement in the partial aggregation observed to patient 2 serum was observed in the presence of $10 \mu \mathrm{g} / \mathrm{ml} \mathrm{PF4}$ (data not shown). Both low and high heparin concentrations $(0.2 \mathrm{U} / \mathrm{ml}$ and $100 \mathrm{U} / \mathrm{ml}$, respectively) prevented serum induced aggregation, although a delayed rather than blocked aggregation was observed to low concentrations in a single patient repeat (Figure 1B and data not shown). Three patients (patients 1,2 and 4) were being given non-heparin anticoagulation with argatroban or fondaparinux at the time of blood collection.

To exclude platelet activation from other sources (such as thrombin and complement) in sera, heat inactivation $\left(56^{\circ} \mathrm{C}, 45\right.$ minutes $)$ of the three patient sera that caused activation was used. ${ }^{15}$ Heat inactivation of patient sera blocked aggregation in two patients and had no effect in another patient (Figure 1b).

\section{Inhibition of cyclooxygenase, $\mathrm{P} \mathrm{Y}_{12}$, Src, Syk and Btk blocks platelet aggregation induced by VITT patient serum}

Platelet activation by FcyRIIA occurs via Src, Syk and Btk kinases. ${ }^{16}$ We tested if clinically available anti-platelet therapies and inhibitors of these kinases could prevent platelet aggregation to patient sera. The Src inhibitor dasatinib, Syk inhibitor entospletinib and the Btk inhibitors ibrutinib and rilzabrutinib all prevented aggregation to patient sera (Figure 2). R406, the active metabolite of the Syk inhibitor fostamatinib, failed to prevent aggregation. The COX inhibitor indomethacin, which has the same mechanism of action as aspirin, and 
medRxiv preprint doi: https://doi.org/10.1101/2021.04.24.21255655; this version posted April 27, 2021. The copyright holder for this preprint (which was not certified by peer review) is the author/funder, who has granted medRxiv a license to display the preprint in perpetuity.

All rights reserved. No reuse allowed without permission.

the $\mathrm{P}_{2} \mathrm{Y}_{12}$ inhibitor ticagrelor also blocked aggregation. All inhibitors were used at a concentration which fully inhibited aggregation to $3 \mu \mathrm{g} / \mathrm{ml}$ collagen (results not shown).

\section{Discussion}

In this study we demonstrate that serum from patients with VITT, but not healthy donors, induces platelet aggregation. Platelet aggregation can be abolished by direct blockade of FcyRIIA with IV.3 F(ab) or IVIg, or through inhibition of its downstream signalling kinases. Anti-platelet drugs targeting secondary mediator pathways of platelet activation also prevented aggregation.

All four patients had similar clinical characteristics to those described in the emergent literature for VITT. 5,6 They all had arterial / venous thrombosis associated with thrombocytopenia, high D-dimers and low fibrinogen. Likewise, all patients were below the age of 50 and presented within two weeks of their first AZD1222 vaccination. Two patients were male and two female. All patients had strongly positive HIT screening tests for antiPF4 antibodies. Interestingly, in VITT patients when the highly sensitive chemiluminescence-based AcuStar test is used to measure anti-PF4 antibodies it is negative. ${ }^{17}$ This raises the possibility that the anti-PF4 antibodies detected by the ELISAbased Immucor test is a false-positive result. ${ }^{18}$ The Immucor assay is known to produce false positive results in the presence of immune complexes or immunoglobulin aggregates. $^{19}$ This is consistent with our results showing no potentiation of platelet aggregation with the addition of excess PF4.

As previously reported, variable aggregation responses on washed platelets from different healthy donors were observed to sera from patients with VITT. ${ }^{5}$ The low aggregation response to patient 2 serum could potentially be explained by treatment with 
medRxiv preprint doi: https://doi.org/10.1101/2021.04.24.21255655; this version posted April 27, 2021. The copyright holder for this preprint (which was not certified by peer review) is the author/funder, who has granted medRxiv a license to display the preprint in perpetuity.

dexamethasone prior to serum collection. Patients 3 and 4 had not received any treatment prior to sera collection, and elicited much greater responses. As is the case with HIT and other VITT studies, washed platelets from certain healthy donors did not respond.,20 Enhancement of platelet activation to serum from patients with VITT in the presence of PF4 has previously been described by Greinacher et al. ${ }^{5}$, which was not observed in this study. A potential explanation for this difference is the nearly three times higher serum concentrations used by Greinacher et al. Blockade of FcyRIIA preventing platelet aggregation (similar to other reports ${ }^{5}$ ) implies activation is likely mediated by clustering of the receptor by $\lg \mathrm{G}$ and immune complexes. We cannot yet however explain the interesting observation that platelet activation was abolished to sera from some patients following heat inactivation. This may reflect a contribution from complement, although normal serum complement levels in VITT patients have been reported. ${ }^{6}$

Immune complexes that activate platelets via FcyRIIA have been reported in critically ill patients with COVID-19. ${ }^{21}$ In these patients, who had been exposed to heparin and displayed thrombocytopenia and thrombosis, HIT was ruled out, due to lack of anti-PF4 antibodies and platelet activation independent of heparin. ${ }^{21}$ Analogous to our findings, platelet activation by these immune complexes could be blocked by both low $(0.1 \& 0.3$ $\mathrm{U} / \mathrm{ml}$ ) and high $(100 \mathrm{U} / \mathrm{ml})$ concentrations of heparin. ${ }^{21}$ Current practise is to withhold heparin anticoagulation from patients with VITT. ${ }^{10}$ Our observation of in vitro platelet aggregation blockade in the presence of heparin may imply this is not necessary. AntiSARS-CoV-2 spike protein IgG antibodies from patients with severe COVID-19 have also been shown to induce apoptosis and increase phosphatidyl serine externalisation in platelets mediated by FcyRIIA, although IgG aggregates or immune complexes were not able to be isolated from patient sera. ${ }^{22}$ It is possible that a similar mechanism is occurring in patients with VITT. Activation of FcyRIIA could give rise to phosphatidyl serine exposure 
medRxiv preprint doi: https://doi.org/10.1101/2021.04.24.21255655; this version posted April 27, 2021. The copyright holder for this preprint (which was not certified by peer review) is the author/funder, who has granted medRxiv a license to display the preprint in perpetuity.

All rights reserved. No reuse allowed without permission.

and procoagulant platelets which may lead to the extensive thrombosis and thrombocytopenia observed in VITT patients.

We screened a variety of clinically used anti-platelet drugs and inhibitors of kinases downstream of FcyRIIA. Blockade was observed to COX (indomethacin), P2Y 12 (ticagrelor), Src (dasatinib), Syk (entospletinib) and Btk (ibrutinib and rilzabrutinib) inhibition. These in vitro findings, suggest a possible role for prophylactic treatment with aspirin (COX inhibitor) following vaccination. However, with the rarity of the syndrome, the risk of such widespread aspirin usage may cause harms - due to the increased risk of bleeding - that outweigh any theoretical benefit. ${ }^{17}$ Aspirin or ticagrelor use is not currently recommended in patients with confirmed VITT due to the already increased bleeding risk associated with the initial thrombocytopenia, reduced fibrinogen and secondary bleeding from CVST. ${ }^{23}$ If, however, ongoing treatment for VITT is required due to ongoing platelet activation following IVIg treatment once there has been partial restoration of the platelet count, then these antiplatelet agents may have a use at this point.

IVIg treatment has been shown to prevent platelet activation in patients with VITT, but is a scarce and expensive resource. ${ }^{24}$ In patients with confirmed VITT, treatment with the Btk inhibitor rilzabrutinib may be a viable alternative. Rilzabrutinib is currently undergoing phase III clinical trials as a treatment to restore platelet counts in immune thrombocytopenia (ITP) with no reports of bleeding or thrombotic events. ${ }^{25}$ Fostamatinib has been used clinically to treat ITP without causing bleeding (and lowering rates of thrombosis ${ }^{26}$ ). However, it did not show effectiveness at blocking platelet activation to patient sera in vitro. Entospletinib, although not associated with bleeding, is not yet in routine use outside of clinical trials and has not been specifically used in thrombocytopenic patients. ${ }^{27}$ All other inhibitors tested have been associated with an increased risk of bleeding and so their use in 
medRxiv preprint doi: https://doi.org/10.1101/2021.04.24.21255655; this version posted April 27, 2021. The copyright holder for this preprint (which was not certified by peer review) is the author/funder, who has granted medRxiv a license to display the preprint in perpetuity.

All rights reserved. No reuse allowed without permission.

thrombocytopenic patients cannot be recommended. ${ }^{28-30}$ Clinical validation of these in vitro findings still needs to be performed.

Limitations of this study are the small sample size, and the difference in treatment patients received prior to sample collection. Additionally, due to the limited amount of sera available and the inter-donor variability of platelet responsiveness to serum, only a limited number of conditions could be tested.

In conclusion, serum from patients with VITT activates platelets via FcyRIIA, which can be blocked in vitro by anti-platelet therapies and downstream kinase inhibitors. This suggests that prophylaxis in at risk groups with commonly used anti-platelet agents such as aspirin may potentially be able to reduce the impact of VITT and that tyrosine kinase inhibitors may be a treatment for clinically manifest VITT in addition to the current management intervention with corticosteroids and IVIg. These strategies, however, require further study.

\section{Acknowledgements}

This work was supported by an Accelerator Grant (AA/18/2/34218) from the British Heart Foundation (BHF). CK is supported by the European Union's Horizon 2020 Research and Innovation Programme under the Marie Skłodowska-Curie Actions Individual Fellowship grant agreement [No 893262], project PAELLA. SPW holds a BHF Chair (CH03/003). The authors would like to thank Dr Mav Manji (University Hospitals Birmingham NHS Foundation Trust) for help with patient recruitment, Charlotte Stoneley for help sourcing patient blood samples, Matt Roberts for information on the Immucor assay and Principia Biopharma for rilzabrutinib.

\section{Declaration of interests}


medRxiv preprint doi: https://doi.org/10.1101/2021.04.24.21255655; this version posted April 27, 2021. The copyright holder for this preprint (which was not certified by peer review) is the author/funder, who has granted medRxiv a license to display the preprint in perpetuity.

All rights reserved. No reuse allowed without permission.

PLRN and SPW have received research grants from Novartis, Principia and Rigel Pharmaceuticals. PLRN has had honoraria from Bayer.

\section{Authorship}

CWS and PLRN designed and performed experiments, analysed data and wrote and revised the manuscript. CK designed and performed experiments and revised the manuscript. YD generated reagents and revised the manuscript. SPW revised the manuscript and designed experiments. GCL and WAL recruited patients, revised the manuscript and contributed intellectually. Underlying data was verified by CWS and PLRN.

\section{References}

1 Polack FP, Thomas SJ, Kitchin N, et al. Safety and Efficacy of the BNT162b2 mRNA Covid-19 Vaccine. N Engl J Med 2020; 383: 2603-15.

2 Baden LR, El Sahly HM, Essink B, et al. Efficacy and Safety of the mRNA-1273 SARS-CoV-2 Vaccine. N Engl J Med 2020; 384: 403-16.

3 Voysey M, Clemens SAC, Madhi SA, et al. Safety and efficacy of the ChAdOx1 nCoV-19 vaccine (AZD1222) against SARS-CoV-2: an interim analysis of four randomised controlled trials in Brazil, South Africa, and the UK. Lancet 2021; 397: 99-111.

4 European Centre for Disease Prevention and Control. Total vaccines doses distributed to EU/EAA countries by vaccine product as of 2021-04-08. Eur. Cent. Dis. Prev. Control COVID-19 Vaccine Tracker. https://vaccinetracker.ecdc.europa.eu/public/extensions/COVID-19/vaccinetracker.html\#distribution-tab (accessed April 8, 2021).

5 Greinacher A, Thiele T, Warkentin TE, Weisser K, Kyrle PA, Eichinger S. Thrombotic Thrombocytopenia after ChAdOx1 nCov-19 Vaccination. N Engl J Med 2021; published online April 9. DOI:10.1056/NEJMoa2104840.

6 Schultz NH, Sørvoll IH, Michelsen AE, et al. Thrombosis and Thrombocytopenia after ChAdOx1 nCoV-19 Vaccination. N Engl J Med 2021; published online April 9. DOI:10.1056/NEJMoa2104882.

7 Medicines and Healthcare products Regulatory Agency UK. MHRA issues new advice, concluding a possible link between COVID-19 Vaccine AstraZeneca and extremely rare, unlikely to occur blood clots. Press Release 7/4/2021. 2021. https://www.gov.uk/government/news/mhra-issues-new-advice-concluding-a- 
medRxiv preprint doi: https://doi.org/10.1101/2021.04.24.21255655; this version posted April 27, 2021. The copyright holder for this preprint (which was not certified by peer review) is the author/funder, who has granted medRxiv a license to display the preprint in perpetuity.

All rights reserved. No reuse allowed without permission.

possible-link-between-covid-19-vaccine-astrazeneca-and-extremely-rare-unlikely-tooccur-blood-clots (accessed April 7, 2021).

8 Greinacher A, Selleng K, Warkentin TE. Autoimmune heparin-induced thrombocytopenia. J Thromb Haemost 2017; 15: 2099-114.

9 Nicolson PLR, Nock SH, Hinds J, et al. Low-dose Btk inhibitors selectively block platelet activation by CLEC-2. Haematologica 2021; 106: 208-19.

10 British Society for Haematology. Guidance produced from the Expert Haematology Panel (EHP) focussed on Covid-19 Vaccine induced Thrombosis and Thrombocytopenia (VITT). 2021. https://b-s-h.org.uk/media/19530/guidance-version13-on-mngmt-of-thrombosis-with-thrombocytopenia-occurring-after-c-19vaccine_20210407.pdf (accessed April 7, 2021).

11 Warkentin TE. High-dose intravenous immunoglobulin for the treatment and prevention of heparin-induced thrombocytopenia: a review. Expert Rev Hematol 2019; 12: 685-98.

12 Rubino JG, Arnold DM, Warkentin TE, Smith JW, Kelton JG, Nazy I. A comparative study of platelet factor 4-enhanced platelet activation assays for the diagnosis of heparin-induced thrombocytopenia. J Thromb Haemost 2021; 19: 1096-102.

13 Vayne C, Guery E-A, Kizlik-Masson C, et al. Beneficial effect of exogenous platelet factor 4 for detecting pathogenic heparin-induced thrombocytopenia antibodies. $\mathrm{Br} \mathrm{J}$ Haematol 2017; 179: 811-9.

14 Padmanabhan A, Jones CG, Curtis BR, et al. A Novel PF4-Dependent Platelet Activation Assay Identifies Patients Likely to Have Heparin-Induced Thrombocytopenia/Thrombosis. Chest 2016; 150: 506-15.

15 Warkentin TE, Arnold DM, Nazi I, Kelton JG. The platelet serotonin-release assay. Am J Hematol 2015; 90: 564-72.

16 Arman M, Krauel K. Human platelet IgG Fc receptor FcyRIIA in immunity and thrombosis. J Thromb Haemost 2015; 13: 893-908.

17 Scully M, Singh D, Lown R, et al. Pathologic Antibodies to Platelet Factor 4 after ChAdOx1 nCoV-19 Vaccination. N Engl J Med 2021; published online April 16. DOI:10.1056/NEJMoa2105385.

18 Favaloro EJ, McCaughan G, Mohammed S, et al. HIT or miss? A comprehensive contemporary investigation of laboratory tests for heparin induced thrombocytopenia. Pathology 2018; 50: 426-36.

19 Immucor. PF4 IgG assay [package insert]. USA: Immucor; 2017. 2017.

20 Warkentin TE, Hayward CPM, Smith CA, Kelly PM, Kelton JG. Determinants of donor platelet variability when testing for heparin-induced thrombocytopenia. J Lab Clin Med 1992; 120: 371-9.

21 Nazy I, Jevtic SD, Moore JC, et al. Platelet-activating immune complexes identified in critically ill COVID-19 patients suspected of heparin-induced thrombocytopenia. $J$ Thromb Haemost 2021; : 1-6.

22 Althaus K, Marini I, Zlamal J, et al. Antibody-induced procoagulant platelets in severe COVID-19 infection. Blood 2021; 137: 1061-71.

23 Zheng SL, Roddick AJ. Association of Aspirin Use for Primary Prevention With 
medRxiv preprint doi: https://doi.org/10.1101/2021.04.24.21255655; this version posted April 27, 2021. The copyright holder for this preprint (which was not certified by peer review) is the author/funder, who has granted medRxiv a license to display the preprint in perpetuity.

All rights reserved. No reuse allowed without permission.

Cardiovascular Events and Bleeding Events: A Systematic Review and Metaanalysis. JAMA 2019; 321: 277-87.

24 Misbah SA, Murphy MF, Pavord S, et al. Outcome of national oversight of intravenous immunoglobulin prescribing in immune thrombocytopenia. J Clin Pathol 2020; 0: 2019-20.

25 Kuter DJ, Boccia R V, Lee E-J, et al. Phase I/II, Open-Label, Adaptive Study of Oral Bruton Tyrosine Kinase Inhibitor PRN1008 in Patients with Relapsed/Refractory Primary or Secondary Immune Thrombocytopenia. Blood 2019; 134: 87.

26 Cooper N, Altomare I, Kreychman Y, et al. Abstracts. PB1356 |Immune Thrombocytopenia Treatment with Fostamatinib, a Spleen Tyrosine Kinase Inhibitor: Reducing the Risk of Thrombosis. Res Pract Thromb Haemost 2020; 4: 1-1311.

27 Awan FT, Thirman MJ, Patel-Donnelly D, et al. Entospletinib monotherapy in patients with relapsed or refractory chronic lymphocytic leukemia previously treated with B-cell receptor inhibitors: results of a phase 2 study. Leuk Lymphoma 2019; 60: 1972-7.

28 Becker RC, Bassand JP, Budaj A, et al. Bleeding complications with the P2Y12 receptor antagonists clopidogrel and ticagrelor in the PLATelet inhibition and patient Outcomes (PLATO) trial. Eur Heart J 2011; 32: 2933-44.

29 Shatzel JJ, Olson SR, Tao DL, McCarty OJT, Danilov A V., DeLoughery TG. Ibrutinibassociated bleeding: pathogenesis, management and risk reduction strategies. $J$ Thromb Haemost 2017; 15: 835-47.

30 Quintás-Cardama A, Kantarjian H, Ravandi F, et al. Bleeding diathesis in patients with chronic myelogenous leukemia receiving dasatinib therapy. Cancer 2009; 115: 2482-90.

Table 1. Summary of Patients with Vaccine Induced Thrombotic Thrombocytopenia (VITT).

\begin{tabular}{|c|c|c|c|c|c|}
\hline & Patient 1 & Patient 2 & Patient 3 & Patient 4 \\
\hline \multicolumn{2}{|r|}{ Age range } & $46-50$ & $31-35$ & $21-25$ & $46-50$ \\
\hline \multicolumn{2}{|r|}{ Sex } & Male & Female & Male & Female \\
\hline \multicolumn{2}{|c|}{$\begin{array}{c}\text { Platelet count at } \\
\text { presentation }\left(\times 10^{9} / \mathrm{L}\right) \\
\text { normal range } 150-450\end{array}$} & 16 & 98 & 113 & 7 \\
\hline \multicolumn{2}{|c|}{$\begin{array}{c}\text { D dimer }(\mathbf{n g} / \mathbf{m L}) \\
\text { normal range } 0-250\end{array}$} & 62342 & 6574 & 22903 & 31301 \\
\hline \multicolumn{2}{|c|}{$\begin{array}{c}\text { Fibrinogen (g/L) } \\
\text { normal range } 1.5-4\end{array}$} & $1 \cdot 2$ & $<0.35$ & 0.98 & $1 \cdot 1$ \\
\hline \multicolumn{2}{|c|}{$\begin{array}{c}\text { Prothrombin Time Ratio } \\
\text { normal range } 0.8-1.2\end{array}$} & $1 \cdot 2$ & 1.5 & $1 \cdot 3$ & $1 \cdot 2$ \\
\hline \multicolumn{2}{|c|}{$\begin{array}{c}\text { Activated Partial } \\
\text { Thromboplastin Time Ratio } \\
\text { normal range } 0.8-1.2\end{array}$} & 1 & $1 \cdot 7$ & 0.8 & $1 \cdot 1$ \\
\hline \multicolumn{2}{|c|}{$\begin{array}{l}\text { HIT Antibody Screen } \\
\text { (Optical density) } \\
\text { normal range } 0.01-0.4\end{array}$} & $2 \cdot 45$ & $2 \cdot 17$ & $2 \cdot 8$ & $>3 \cdot 0$ \\
\hline$=\frac{\frac{0}{0}}{\frac{\pi}{\alpha}}+\frac{j}{8}$ & $\begin{array}{l}\text { Platelet activation } \\
\text { with serum normal } \\
\text { range } \leq 8 \%\end{array}$ & $24 \cdot 79 \%$ & $31 \cdot 2 \%$ & $55 \%$ & $\begin{array}{c}\mathrm{N} / \mathrm{A} \\
\text { (not done) }\end{array}$ \\
\hline
\end{tabular}


medRxiv preprint doi: https://doi.org/10.1101/2021.04.24.21255655; this version posted April 27, 2021. The copyright holder for this preprint (which was not certified by peer review) is the author/funder, who has granted medRxiv a license to display the preprint in perpetuity. All rights reserved. No reuse allowed without permission.

\begin{tabular}{|c|c|c|c|c|}
\hline $\begin{array}{c}\begin{array}{c}\text { Platelet activation } \\
\text { with serum and } \\
\text { heparin }\end{array} \\
\text { normal range } \leq 8 \%\end{array}$ & $18 \cdot 53 \%$ & $18 \%$ & $36 \cdot 5 \%$ & $\begin{array}{c}\mathrm{N} / \mathrm{A} \\
\text { (not done) }\end{array}$ \\
\hline $\begin{array}{l}\text { Platelet activation } \\
\text { with serum and } \\
\text { excess heparin } \\
\text { normal range } \leq 8 \%\end{array}$ & $0.64 \%$ & $3 \cdot 68 \%$ & $1 \cdot 43 \%$ & $\begin{array}{c}\mathrm{N} / \mathrm{A} \\
\text { (not done) }\end{array}$ \\
\hline Clinical & CVST & CVST & Ischaemic stroke & CVST \\
\hline $\begin{array}{c}\text { Number of days post } \\
\text { vaccine at presentation }\end{array}$ & 14 & 12 & 10 & 14 \\
\hline Presentation symptoms & $\begin{array}{l}\text { Headaches; } \\
\text { Haematuria; } \\
\text { Petechial rash; } \\
\text { Subsequent } \\
\text { development of } \\
\text { left sided } \\
\text { weakness }\end{array}$ & $\begin{array}{l}\text { Occipital } \\
\text { headache }\end{array}$ & $\begin{array}{l}\text { Headache for 2-3 } \\
\text { days; Collapse; } \\
\text { Expressive } \\
\text { dysphasia; } \\
\text { Lack of } \\
\text { coordination }\end{array}$ & Headache \\
\hline $\begin{array}{l}\text { Imaging findings at } \\
\text { presentation }\end{array}$ & $\begin{array}{l}\text { CVST } \\
\text { Subarachnoid } \\
\text { haemorrhage }\end{array}$ & $\begin{array}{c}\text { CVST } \\
\text { Subarachnoid } \\
\text { haemorrhage } \\
\text { intraparenchymal } \\
\text { haemorrhage } \\
\end{array}$ & $\begin{array}{l}\text { Acute left ICA } \\
\text { thrombus with } \\
\text { multiple left } \\
\text { middle MCA } \\
\text { territory infarctions }\end{array}$ & $\begin{array}{c}\text { CVST } \\
\text { intraparenchymal } \\
\text { haemorrhage }\end{array}$ \\
\hline $\begin{array}{c}\text { Immunosuppression regime } \\
\text { used }\end{array}$ & $\begin{array}{l}\text { IVIg } 0.5 \mathrm{~g} / \mathrm{kg} \text { OD } \\
\text { for } 2 \text { consecutive } \\
\text { days } \\
\text { Dexamethasone } \\
20 \mathrm{mg} \text { OD for } 3 \\
\text { days }\end{array}$ & $\begin{array}{l}\text { IVIg } 1 \mathrm{~g} / \mathrm{kg} \text { for } 2 \\
\text { consecutive days } \\
\text { Dexamethasone } \\
40 \text { mg OD for } 4 \\
\text { days }\end{array}$ & $\begin{array}{l}\text { IVIg } 1 \mathrm{~g} / \mathrm{kg} \text { single } \\
\text { dose } \\
\text { Dexamethasone } \\
40 \text { mg OD for } 4 \\
\text { days }\end{array}$ & $\begin{array}{c}\text { IVIg } 1 \mathrm{~g} / \mathrm{kg} \text { single } \\
\text { dose using dose } \\
\text { determining } \\
\text { weight formula } \\
\text { Dexamethasone } \\
40 \text { mg OD for } 4 \\
\text { days. }\end{array}$ \\
\hline $\begin{array}{l}\text { Anticoagulant / Antiplatelet } \\
\text { regime used }\end{array}$ & $\begin{array}{c}\text { Argatroban } \\
\text { Fondaparinux } \\
7 \cdot 5 \mathrm{mg} \text { SC OD } \\
\text { (when platelets } \\
\text { and renal function } \\
\text { recovered) }\end{array}$ & Argatroban & $\begin{array}{c}\text { Fondaparinux } \\
7 \cdot 5 \mathrm{mg} \text { OD } \\
\text { Apixaban 5mg BD }\end{array}$ & $\begin{array}{c}\text { Fondaparinux } \\
2.5 \mathrm{mg} \mathrm{SC} \text { OD } \\
\text { (whilst platelets } \\
<50 \times 10^{9} / \mathrm{L} \text { ) } \\
\text { Fondaparinux } \\
7.5 \mathrm{mg} \text { SC OD } \\
\text { (when platelets } \\
\geq 50 \times 10^{9} / \mathrm{L} \text { ) } \\
\\
\text { Dabigatran } 150 \mathrm{mg} \\
\mathrm{BD} \text { (on discharge) }\end{array}$ \\
\hline Timing of first serum sample & $\begin{array}{l}\text { Post-IVlg and } \\
\text { Dexamethasone }\end{array}$ & $\begin{array}{c}\text { Post-single dose } \\
\text { of } \\
\text { Dexamethasone }\end{array}$ & Pre-treatment & Pre-treatment \\
\hline $\begin{array}{l}\text { Timing of second serum } \\
\text { sample }\end{array}$ & $\mathrm{N} / \mathrm{A}$ & $\begin{array}{l}\text { Post -IVIg and } \\
\text { Dexamethasone }\end{array}$ & $\begin{array}{l}\text { Post-IVIg and } \\
\text { Dexamethasone }\end{array}$ & $\begin{array}{l}\text { Post-IVIg and } \\
\text { Dexamethasone }\end{array}$ \\
\hline $\begin{array}{l}\text { Days post IVIg that platelet } \\
\text { count rose } \\
>50 \times 10^{9} / \mathrm{L}\end{array}$ & $\begin{array}{c}\mathrm{N} / \mathrm{A} \\
\text { - Nadir } 59 \times 10^{9} / \mathrm{L} \\
\text { (platelets } 100 \\
\times 10^{9} / \mathrm{L} 48 \text { hours } \\
\text { after first IVIg } \\
\text { infusion) }\end{array}$ & 2 days & $\begin{array}{c}\mathrm{N} / \mathrm{A} \\
\text { - nadir } 52 \times 10^{9} / \mathrm{L} \\
\text { (Platelets } 198 \\
\times 10^{9} / \mathrm{L} \text { three days } \\
\text { after IVIg infusion) }\end{array}$ & 3 days \\
\hline Outcome & $\begin{array}{c}\text { Clinically } \\
\text { recovered at time } \\
\text { of discharge from } \\
\text { hospital after } 26 \\
\text { day admission }\end{array}$ & $\begin{array}{c}\text { Death } \\
\text { (support } \\
\text { withdrawn } \\
\text { following } \\
\text { confirmation of }\end{array}$ & $\begin{array}{c}\text { Clinically } \\
\text { recovered at time } \\
\text { of discharge from } \\
\text { hospital after a } 10 \\
\text { day admission }\end{array}$ & $\begin{array}{c}\text { Clinically } \\
\text { recovered at time } \\
\text { of discharge from } \\
\text { hospital after a } 16 \\
\text { day admission }\end{array}$ \\
\hline
\end{tabular}


medRxiv preprint doi: https://doi.org/10.1101/2021.04.24.21255655; this version posted April 27, 2021. The copyright holder for this preprint (which was not certified by peer review) is the author/funder, who has granted medRxiv a license to display the preprint in perpetuity.

All rights reserved. No reuse allowed without permission.

\begin{tabular}{|l|l|l|l|l|}
\hline & & brainstem death) & & \\
& & & & \\
\hline
\end{tabular}

BD, twice daily; Continuous positive airway pressure, CPAP; CVST, Cerebral venous sinus thrombosis; ICA, Internal carotid artery; IVIg, intravenous immunoglobulin; MCA, Middle cerebral artery; N/A, Not available; OD, once daily; SC, Subcutaneous. 
medRxiv preprint doi: https://doi.org/10.1101/2021.04.24.21255655; this version posted April 27, 2021. The copyright holder for this preprint

(which was not certified by peer review) is the author/funder, who has granted medRxiv a license to display the preprint in perpetuity.

All rights reserved. No reuse allowed without permission.

\section{Figure legends}

Figure 1. Serum from patients with VITT induces platelet aggregation via the FcyRIIA. Washed platelets $\left(2 \times 10^{8} / \mathrm{ml}\right)$ were stimulated with serum $(1: 15, \mathrm{v} / \mathrm{v})$ from $(\mathbf{A})$ healthy donors (HD) or patients with VITT (P) pre- and post-IVIg treatment, or (B) in the presence of 10 $\mu \mathrm{g} / \mathrm{ml} \mathrm{IV.3} \mathrm{F}(\mathrm{ab})$, low concentration heparin $(0.2 \mathrm{U} / \mathrm{ml})$ or following heat inactivation $\left(56^{\circ} \mathrm{C}\right.$, 45 minutes) and aggregation measured. (i) Representative aggregation traces and (ii) quantification of maximum aggregation. Mean $\pm S E M, n=3$. Statistical analysis was by twoway ANOVA with Dunnett multiple comparisons, * $p<0 \cdot 05$, ns: non-significant.

Figure 2. Inhibition of cyclooxygenase, $\mathrm{P}_{2} \mathrm{Y}_{12}, \mathrm{Src}$, Syk and Btk block platelet aggregation induced by serum from patients with VITT. Washed platelets $\left(2 \times 10^{8} / \mathrm{ml}\right)$ were incubated with indomethacin $(10 \mu \mathrm{M})$, ticagrelor $(1 \mu \mathrm{M})$, dasatinib $(1 \mu \mathrm{M})$, R406 $(1$ $\mu \mathrm{M})$, entospletinib $(1 \mu \mathrm{M})$, ibrutinib $(0.5 \mu \mathrm{M})$, rilzabrutinib $(0.5 \mu \mathrm{M})$ or vehicle $(0.02 \%$ DMSO) for 10 minutes then stimulated with serum $(1: 15, \mathrm{v} / \mathrm{v})$ from patients with VITT. (A) Representative aggregation traces and (B) quantification of maximum aggregation. Mean \pm $\mathrm{SEM}, \mathrm{n}=7$. Statistical analysis was by one-way ANOVA with Dunnett multiple comparisons, ${ }^{*} \mathrm{p}<0 \cdot 05$, ns: non-significant. 
Figure 1

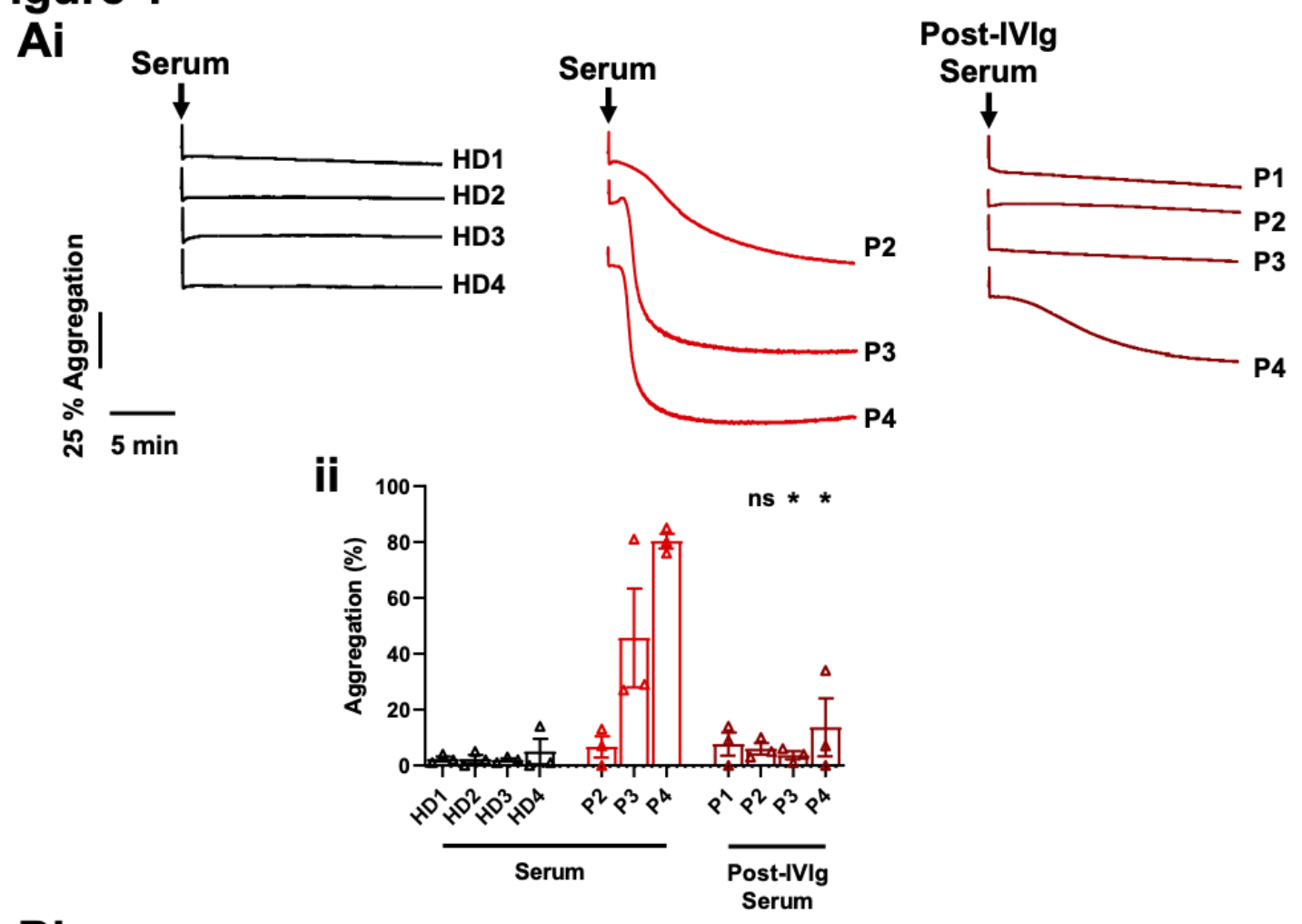

Bi

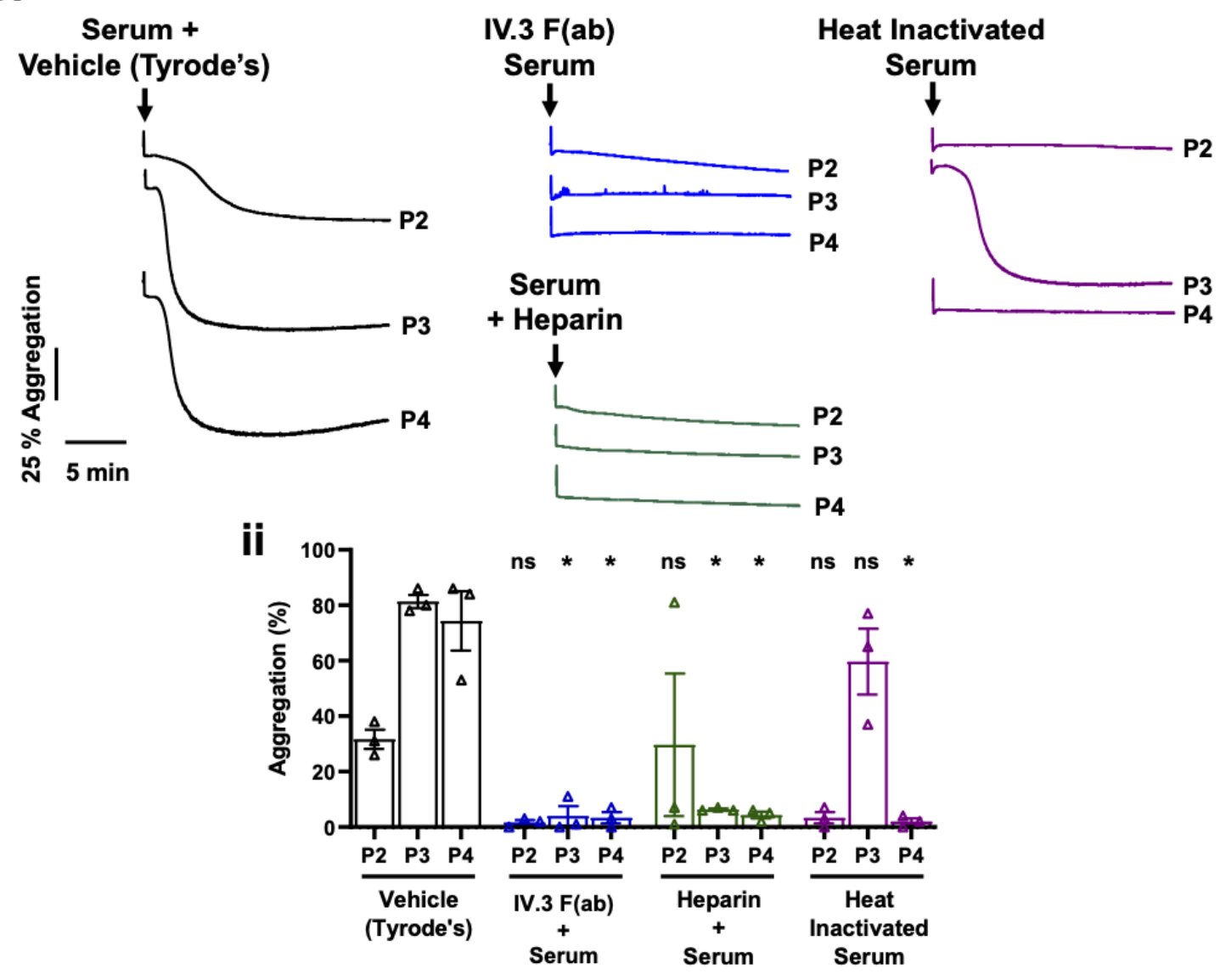




\section{Figure 2}

A

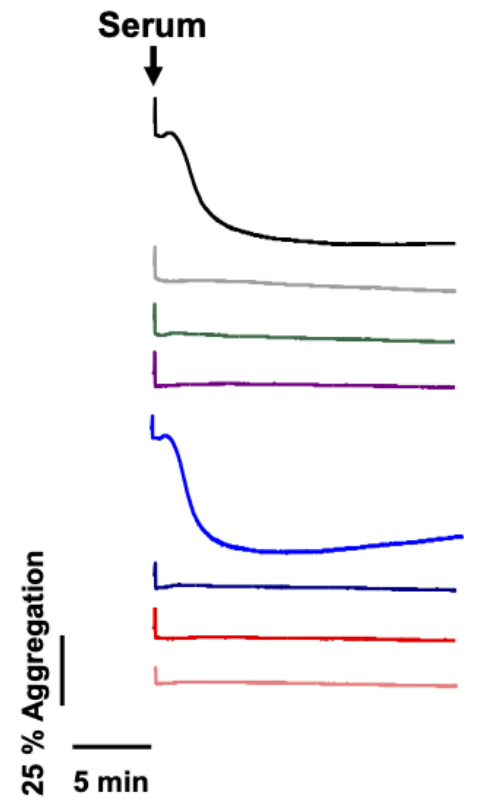

B

Vehicle $(0.02 \%$ DMSO) Indomethacin $10 \mu \mathrm{M}$

Ticagrelor $1 \mu \mathrm{M}$

Dasatinib $1 \mu \mathrm{M}$

R406 $1 \mu \mathrm{M}$

Entospletinib $1 \mu \mathrm{M}$

lbrutinib $0.5 \mu \mathrm{M}$

Rilzabrutinib $0.5 \mu \mathrm{M}$
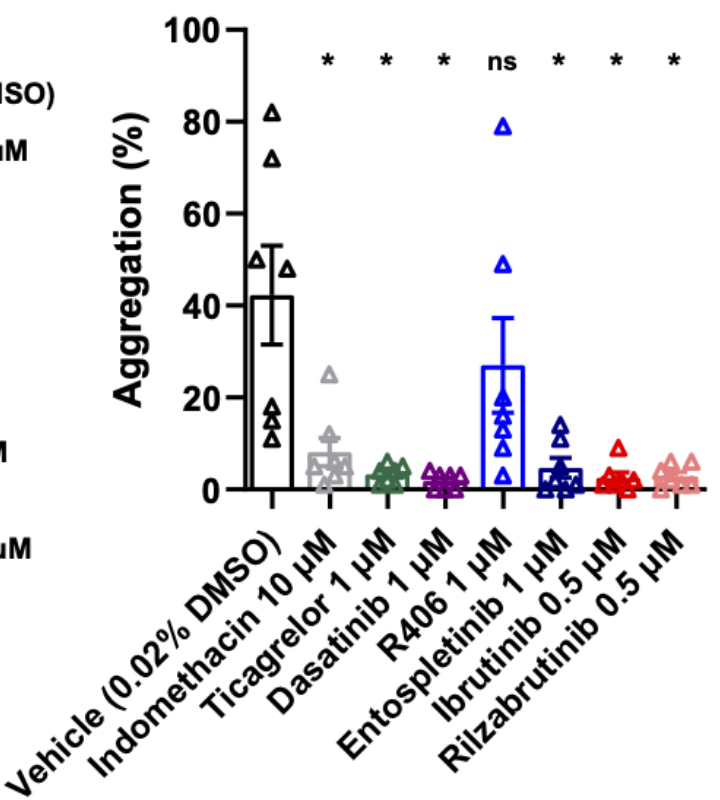
medRxiv preprint doi: https://doi.org/10.1101/2021.04.24.21255655; this version posted April 27, 2021. The copyright holder for this preprint (which was not certified by peer review) is the author/funder, who has granted medRxiv a license to display the preprint in perpetuity.

All rights reserved. No reuse allowed without permission. 